\title{
LEVELS AND SOURCES OF PCDDS, PCDFS AND dl-PCBS IN THE WATER ECOSYSTEMS OF CENTRAL POLAND - A MINI REVIEW
}

\author{
MAREK ZIELIŃSKI ${ }^{1}$, JOANNA KAMIŃSKA ${ }^{1}$, MARTA CZERSKA ${ }^{1}$, DANUTA LIGOCKA ${ }^{1}$, \\ and MAGDALENA URBANIAK ${ }^{2,3}$ \\ ${ }^{1}$ Nofer Institute of Occupational Medicine, Łódź, Poland \\ Department of Toxicology and Carcinogenesis \\ ${ }^{2}$ Polish Academy of Sciences, Łódź, Poland \\ European Regional Centre for Ecohydrology \\ ${ }^{3}$ University of Lodz, Lódź, Poland \\ Department of Applied Ecology
}

\begin{abstract}
Polychlorinated dibenzo-p-dioxins (PCDDs) and dibenzofurans (PCDFs) are unwanted by-products in a variety of industrial and thermal processes. They have been present on Earth long before the human era, since they may be also formed as a result of forest fires or volcanic explosions. Polychlorinated biphenyls (PCBs) in turn, have been intentionally produced by humans. Poland was a minor producer of PCB mixtures (Chlorofen and Tarnol), which were a source of direct and indirect environmental diffusion with PCB and less with PCDDs/PCDFs. Industrial accidents with PCDDs/PCDFs were absent in Poland. Their stability and resistance to thermal breakdown made them very dangerous for environment and, in consequence, due to their environmental persistence, bioaccumulation and biomagnification in the terrestrial and aquatic food chains, to humans. Humans may become affected by PCDDs/PCDFs and PCBs through environmental (soil and water contamination, fish and food), occupational (incinerators; pulp, paper and metallurgy industry; copper production), or accidental (Seveso accident) exposure. The aim of this review was to evaluate environmental hazard caused by PCDDs, PCDFs and dioxin-like-PCBs in the central region of Poland based on the accessible data on diffusion of those compounds in sediments and riverine, reservoir and storm water from our previous studies and discussed in the context of other achievements in Poland and elsewhere.
\end{abstract}

\section{Keywords:}

Environment, Isotope dilution HRGC/HRMS, PCDDs/PCDFs, dl-PCBs, Sediments, Surface water

\section{INTRODUCTION}

Recently, in Europe, more than 30000 chemicals are produced and processed in the amount of more than 1 tone each year [1]. In this situation, water ecosystems which are located in the lowest parts in the catchments are contaminated with bulk mass of various kinds of chemicals, including persistent organic pollutants (POPs). Environmental pollution with POPs including polychlorinated dibenzo-p-dioxins (PCDDs), polychlorinated dibenzofurans (PCDFs) and polychlorinated biphenyls (PCBs), has

Received: December 12, 2013. Accepted: August 17, 2014.

Corresponding author: M. Zieliński, Nofer Institute of Occupational Medicine, Department of Toxicology and Carcinogenesis, św. Teresy 8, 91-348 Łódź, Poland (e-mail: marek.zielinski78@gmail.com). 
become a very important toxicological problem during the last 30 years. Production of PCBs has been banned for many years and waste containing those compounds was subjected to safe disposal largely before 2010, therefore, global emission of PCBs and also PCDDs/PCDFs has been largely reduced during the recent 2 decades. Nevertheless, because of past uses and diffusion as well as actual emissions from secondary sources, including some industrial processes, and known physical, chemical and environmental persistency and toxicity of those compounds, they still constitute risk to human health and other biota. These lipophilic and persistent contaminants have been present in the environment for a long time. They have been present on Earth a long time before the human era, since they may be also formed as a result of forest fires and fires in buildings, or volcanic explosions, which have been very important sources of these compounds [2]. They were even detected in soil samples from a Roman brickworks along the Lower Rhine near Dormagen, dating back to about 50 before Christ (B.C.) [3]. Physical and chemical stability and resistance to thermal breakdown and high toxicity made them highly hazardous to humans and other living organisms due to bioaccumulation and biomagnification in food chains.

Today, also accidental fires are a very important source of PCDDs/PCDFs as they release to the land a range from 7.50 to $240 \mathrm{~g}$ of TEQ (the Total Toxic Equivalency)/ year [4]. Polychlorinated dibenzo-p-dioxins and polychlorinated dibenzofurans and other compounds of similar nature are byproducts in various chlorinated chemical formulations, while PCBs have been produced commercially and have been used in a variety of applications since 1929 [5]. Additionally, they are produced unintentionally in thermal reactions.

Polychlorinated dibenzo-p-dioxins, polychlorinated dibenzofurans and polychlorinated biphenyls exist as complex mixtures of different congeners. There are 210 congeners of PCDDs and PCDFs (75 and 135, respectively) and 209 PCB congeners for which the International Union of Pure and Applied Chemistry (IUPAC) nomenclature and numbering system was adopted [6]. A Group of Experts from the International Agency for Research on Cancer (IARC), on the basis of evidence of an AhRmediated mechanism of carcinogenicity in humans and experimental animals, classified PCDDs/PCDFs and dlpolychlorinated biphenyls (dl-PCBs) as carcinogenic to humans and thus, they are included in Group 1. From meta-analyses of the available toxicological data and those derived based on AhR mediated mechanism of action, 2,3,7,8-tetrachlorodibenzo-p-dioxin (TeCDD) is considered the most toxic individual among all PCDDs/ PCDFs and dl-PCBs. That is why their presence in environment is of great concern.

Although dioxin studies have been conducted for over 40 years, there is still little data on the pollution with those compounds in Poland, and the knowledge about environmental pollution with PCDDs, PCDFs and dl-PCBs is insufficient when compared to many other countries. Nonetheless, until now, several research has focused on manufacture, use, inventory and disposal of PCBs in Poland [7]; as well as on composition of PCB isomers and congeners in technical Chlorofen formulation $[8,9]$.

There are also not satisfactory, relevant legal regulations on this issue. Legal requirements stimulate actions towards reduction of the emissions of these compounds, which led to a $60 \%$ decrease of POPs emissions in 2000 compared to 1988 [10]. Poland, after signing the Stockholm Convention, is obliged to report data on annual emissions of pollutants, including POPs. Nevertheless, majority of the research has been carried out on food and fish samples [11-13]. The results obtained by Lizak et al. [14] using high resolution gas chromatography / high resolution mass spectrometry (HRGC/HRMS) showed that of 78 samples of examined foodstuffs, in 18 cases concentrations of toxic compounds exceeded acceptable limits [15]. Moreover, 
breast milk monitoring programs have been carried out in various countries including Poland [16-18] in order to assess the significance of human exposure to PCDDs/PCDFs and PCBs. The most important benefit of monitoring dioxins in breast milk is that the dose delivered to the infant can be estimated [19]. Knowledge concerning breast milk contamination and thus, a proper assessment of the risks to the child will facilitate development of programs to improve the security of food for women and children and, consequently, the health of the newborns.

Apart from human tissues, soil, water and sediments also pine needles are tested for the presence of PCDDs/PCDFs and PCBs, as they are cost effective and also easy collectable matrices, which are very helpful in long-term monitoring of the pollution with these compounds. Pine needles were collected in Poland, near Kraków and Katowice cities, in 2002 [20,21]. The results ranged from $2.7-50 \mathrm{ng} / \mathrm{g}$ wet weight (w.w.), with dl-PCB concentrations ranging from 0.21-1.54 pg TEQ/g w.w. [20]. As the authors observed, concentrations of PCBs in pine needles were higher when compared to the soil levels, therefore, they claimed that they are a good biomatrix for long-term monitoring of an ambient air pollution.

Despite this, the data on the PCDDs/PCDFs and dl-PCB concentrations in the aquatic environment compartments such as water, storm water, sediments, etc. are very scarce. Hence, this paper summarized accessible results from the studies on environmental matrices like sediments, rivers and reservoir and storm water in the urban and rural areas of central Poland. An attempt was also made to evaluate data on PCDDs/PCDFs and dl-PCBs available for some environmental matrices from several locations worldwide.

\section{Location and description of the studied ecosystems}

The data described in this paper were discussed using the results of own research conducted in the past few years and analysis of literature concerning contamination of water ecosystem in Poland. In particular, the results of water, sediments and storm water samples collected from 2 kinds of water ecosystems, and widely described in publications, were examined. The analyzed materials were collected from the 2 following water ecosystems:

1. Urban - there are 3 main global problems with water and water ecosystems, especially relating to urban areas: high density of development has a huge impact on the water and heat balance; ageing technical infrastructure designed for collection and treatment of sewage and drainage of storm water; impact of these changes shown above on ecological security and quality of life of a large number of people per $1 \mathrm{~m}^{2}$ [22]. Most of the measured sediments and water samples came from Sokołówka River, situated in central Poland, in the city of Łódź, the 3rd biggest city in Poland. Thus, the presented data reflect the pollution level in water ecosystems located in the highly urbanized and industrialized catchment. Most of the length of Sokołówka River is within the territory of Łódź and it may be contaminated with organic compounds, including PCDDs/PCDFs and heavy metals coming with sewage and storm water [23]. The water and sediment samples were collected from the river as well as from 5 small reservoirs of approximately 0.5 to 1.5 ha surface located along its continuum [23].

2. Rural - a strictly rural ecosystem was represented by small Barycz Reservoir situated in the middle reaches of Grabia, known to be one of the least polluted rivers in central Poland $[24,25]$. A similar catchment was also represented by Sulejowski Reservoir. Nevertheless, opposite to the Barycz Reservoir, it represents a large and shallow reservoir situated in the middle reaches of the Pilica River.

\section{Levels of PCDDs/PCDFs and dl-PCBs}

\section{in the urban and rural reservoir sediments}

The PCDDs/PCDFs and dl-PCBs are characterized by the low volatility and low solubility in water. These properties 
predispose them to associate with organic matter and deposit in the sediments. In the case of dam reservoirs, wherein the flow velocity decreases and consequently the amount of suspended matter increases, the process of deposition and accumulation of PCDDs/PCDFs and dl-PCBs is accelerated [26]. Therefore, reservoir sediments are frequently used for monitoring the water ecosystems stress.

The obtained results presented by Urbaniak et al. [25] demonstrated that the PCDDs/PCDFs concentrations ranged from $213 \mathrm{pg} / \mathrm{g}$ dry weight (d.w.) in the rural Barycz Reservoir, up to $536 \mathrm{pg} / \mathrm{g}$ d.w. in the Lower Pond located on the urban Sokołówka River. The authors also demonstrated that, in all the analyzed sediment samples the octachlorodibenzo-p-dioxin (OCDD) congener dominated and ranged from $162 \mathrm{pg} / \mathrm{g}$ d.w. (76\% of the total PCDDs/PCDFs) in the case of rural, up to $410 \mathrm{pg} / \mathrm{g}$ d.w.
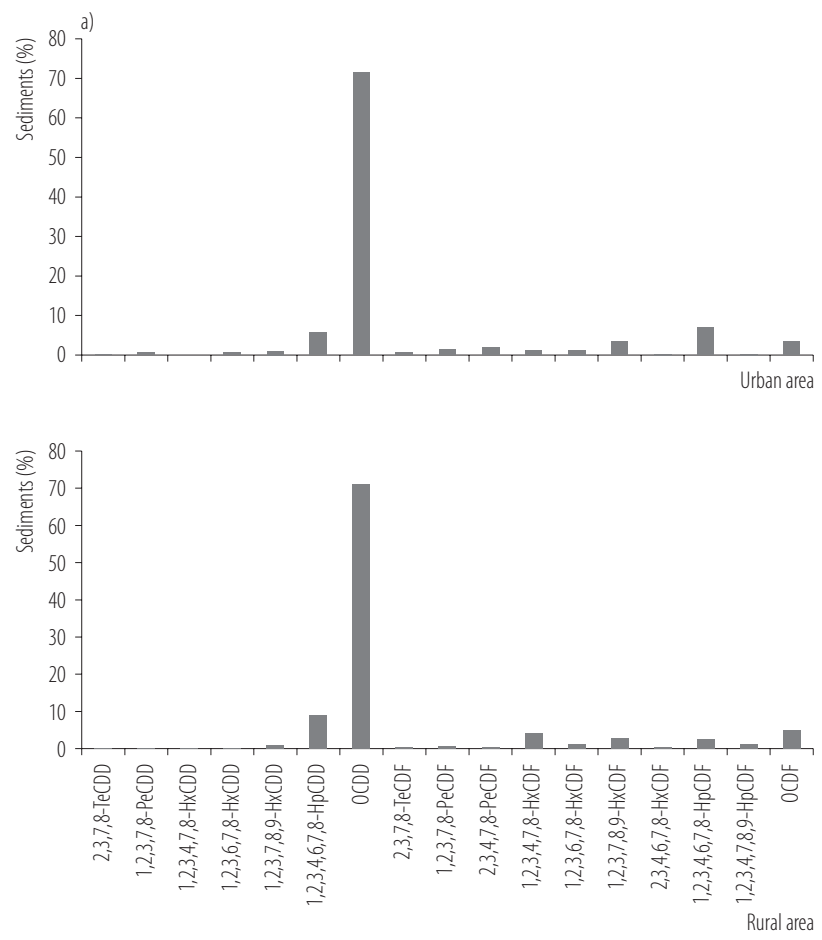

(also $76 \%$ of the total PCDDs/PCDFs) in the case of urban reservoir sediments (Figure 1) [24,25].

Moreover, in all the analyzed sediment samples the tetraand penta-chlorodibenzo-p-dioxin (TeCDD and PeCDD) congeners were not detected, whereas the hexa- and hepta-CDDs showed slight contribution to the total PCDDs/ PCDFs. In the case of the concentrations expressed as World Health Organization Total Toxic Equivalency (WHO-TEQ) (calculated on the basis of the toxic equivalency factors (TEF) WHO 2005 values), the obtained values ranged from 2.32 to $7.98 \mathrm{pg}$ TEQ/g d.w. for the rural reservoir and urban pond, respectively $[24,25]$.

In comparison, results of PCDDs and PCDFs determinations in the sediments of one of the largest water reservoirs in central Poland - Sulejowski Reservoir, located in prevailing agricultural catchment, showed a much
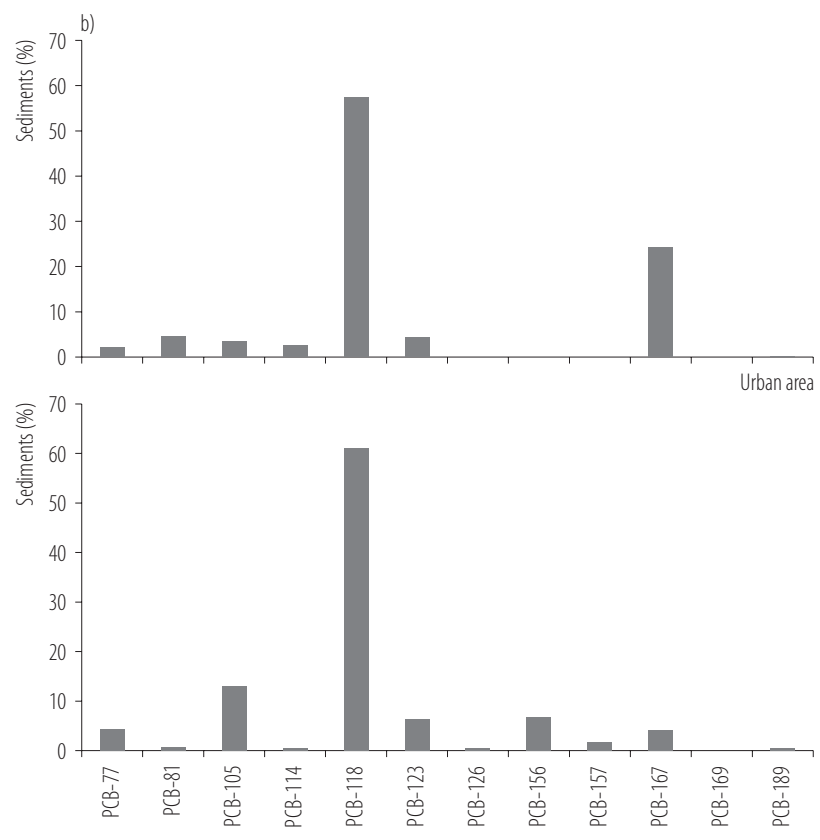

TeCDD - tetrachlorodibenzo-p-dioxin; PeCDD - pentachlorodibenzo-p-dioxin; HxCDD - heksachlorodibenzo-p-dioxin; HpCDD - heptachlorodibenzo-p-dioxin; OCDD - octachlorodibenzo-p-dioxin; TeCDF - tetrachlorodibenzofuran; PeCDF - pentachlorodibenzofuran; HxCDF - heksachlorodibenzofuran; HpCDF - heptachlorodibenzofuran; OCDF - octachlorodibenzofuran.

Fig. 1. Profile of a) polychlorinated dibenzo-p-dioxins/furans (PCDDs/PCDFs) and b) dioxin-like polychlorinated biphenyls (dl-PCB) in sediment samples from rural and urban areas [24,25] 
lower TEQ values ranging from 0.73 to $3.07 \mathrm{pg}$ TEQ/g d.w. (with average value of $1.73 \mathrm{pg}$ TEQ/kg d.w.) [27-29] and the total PCDDs/PCDFs and dl-PCBs concentration ranging from 17.49 to $454.97 \mathrm{pg} / \mathrm{g}$ d.w. The results from the Sulejowski Reservoir sediments analysis also demonstrated a strong predominance of the sum of PCDD congeners (85\% of the total PCDDs/PCDFs) with the elevated OCDD congener concentration [27-29]. Similar results were reported in the studies of Waszak and Dąbrowska [29] and Seike et al. [30]. The further study of Urbaniak et al. [26] concerning spatial distribution of PCDDs/PCDFs along the cascade of urban reservoirs, revealed a similar pattern with elevated OCDD congener content ranging from $19.3 \%$ up to $93.2 \%$ of the total PCDDs/PCDFs.

The data described above clearly demonstrate similar PCDDs/PCDFs profile for sediments collected from urban as well as from rural catchments, with the predominance of the OCDD in over 70\% of all the PCDDs/ PCDFs congeners. The other dominant congeners were 1,2,3,4,6,7,8-heptachlorodibenzofuran (HpCDF) and 1,2,3,4,6,7,8-heptachlorodibenzo-p-dioxin (HpCDD), which accounted for $7 \%$ and $6 \%$ of all the PCDD and PCDF congeners, respectively in urban area and 1,2,3,4,6,7,8-HpCDD and octachlorodibenzo-p-dioxin (OCDF) which accounted for $9 \%$ and $5 \%$ of all the PCDD and PCDF congeners in rural areas. This findings are in contrast with concentrations and ratios of PCDDs/PCDFs in very contaminated sediments from one of the most polluted rivers in Taiwan [31]. This reverse can be related to the impact of road transport in the area of Taiwan and thus, an elevated content of PCDF congeners.

The studies of Hagenmaier et al. [32], Geureke et al. [33], Ryan and Gullet [34] have shown that the elevated proportion of PCDFs is related to their emission from the diesel engines. The earlier study of Urbaniak et al. 2012 [23] also demonstrated an elevated concentrations of PCDDs/ PCDFs in river water samples collected near a busy street.
The significant predominance of PCDF congeners is also noted for municipal solid waste incineration [35]. No such predominance in Łódź area and Sulejowski Reservoir catchment is probably attributable to the fact that there is no industrial equipment, which could be a source of those compounds, in that area. Polychlorinated dibenzo-p-dioxins and dibenzofurans were also determined in sediments collected from Odra and Wisła rivers [36]. The highest toxicity was observed along the profile at Kwidzyn, and this value was much lower than the toxicity observed in the highly contaminated rivers in Taiwan (up to $14200 \mathrm{pg} / \mathrm{g}$ ) or in Rhine river in Germany [31,37]. Hence, the authors concluded that the rivers in Poland are less contaminated with PCDDs/PCDFs as compared to the other rivers, even in Europe. Here, also OCDD congener is among the most significant values.

Another research in sediments collected from Odra river was conducted by Kannan et al. [38]. Concentrations of PCBs in sediments ranged from 2.7 to $412 \mathrm{ng} / \mathrm{g}$. In another research, of Niemirycz et al. [39], 60\% of concentrations of the sum of congeners PCDDs/PCDFs in bottom sediments of the Southern Baltic did not exceed the limit value (5 pg I-TEQ (International Toxic Equivalency)/g d.w. - the limit value concerned uncontaminated regions) [40,41]. The levels of pollution of rivers and reservoir sediments in Poland are shown in Table 1, whereas the worldwide pollution is presented in Table 2 .

In contrast, urban reservoir sediments collected from Sokołówka showed a much higher PCDDs/PCDFs values ranging from 282.2 to $11351 \mathrm{pg} / \mathrm{g}$. At the same time PCDDs/ PCDFs concentration in the sediments collected from Ethiopian reservoirs reached $4752 \mathrm{pg} / \mathrm{g}$ at maximum. In contrast, concentrations in terms of WHO-TEQ were higher in Ethiopian samples (range: 4-212 pg TEQ/g), whereas in the Polish samples the corresponding values ranged from 2 to $19 \mathrm{pg}$ TEQ/g [27].

In the case of PCBs levels in urban and rural reservoir sediments, the findings showed a significantly higher PCBs 
Table 1. Levels of PCDDs, PCDFs and dl-PCBs and WHO-TEQ concentrations determined in reservoir and river sediments in the region of central Poland

\begin{tabular}{|c|c|c|}
\hline Measured compound & Concentration & Reference \\
\hline \multicolumn{3}{|l|}{ Large reservoir (Włocławek and Sulejowski) } \\
\hline the sum of PCDDs/PCDFs and dl-PCBs & $10.80-162.70$ ng/kg d.w. & 27 \\
\hline WHO-TEQ & 1.13-4.13 ng TEQ/kg d.w. & \\
\hline \multicolumn{3}{|l|}{ Large reservoir (Sulejowski) } \\
\hline the sum of PCDDs/PCDFs & $282.20-1012.00 \mathrm{ng} / \mathrm{kg}$ d.w. & 29 \\
\hline WHO-TEQ & $1.73-10.20 \mathrm{ng} T E Q / \mathrm{kg}$ d.w. & \\
\hline \multicolumn{3}{|l|}{ Small reservoir (Włocławek and Sulejowski) } \\
\hline the sum of PCDDs/PCDFs and dl-PCBs & 11351.00 ng/kg d.w. & 27 \\
\hline WHO-TEQ & 18.89 ng TEQ/kg d.w. & \\
\hline \multicolumn{3}{|l|}{ Small reservoirs on Sokołówka River (Łódź) } \\
\hline the sum of dl-PCBs & 79.75-3741.00 ng/kg d.w. & 57 \\
\hline \multicolumn{3}{|l|}{ Sokołówka Reservoir - urbanized catchment } \\
\hline the sum of dl-PCBs & 694.30 ng/kg d.w. & 24,25 \\
\hline WHO-TEQ & 1.42 ng TEQ/kg d.w. & \\
\hline the sum of PCDDs/PCDFs & $536.30 \mathrm{ng} / \mathrm{kg}$ d.w. & \\
\hline WHO-TEQ & 7.98 ng TEQ/kg d.w. & \\
\hline \multicolumn{3}{|l|}{ Jeziorsko Reservoir - large urban/rural catchment } \\
\hline the sum of dl-PCBs & $121.40 \mathrm{ng} / \mathrm{kg}$ d.w. & \\
\hline WHO-TEQ & 0.27 ng TEQ/kg d.w. & \\
\hline \multicolumn{3}{|l|}{ Barycz Reservoir - rural catchment } \\
\hline the sum of dl-PCBs & $350.00 \mathrm{ng} / \mathrm{kg}$ d.w. & \\
\hline WHO-TEQ & 0.40 ng TEQ/kg d.w. & \\
\hline the sum of PCDDs/PCDFs & 213.70 ng/kg d.w. & \\
\hline WHO-TEQ & $2.32 \mathrm{ng} \mathrm{TEQ} / \mathrm{kg}$ d.w. & \\
\hline \multicolumn{3}{|c|}{ Small reservoirs on Sokołówka River (Łódź) - highly urbanized region } \\
\hline the sum of PCDDs/PCDFs and dl-PCBs & $22.98-254.60 \mathrm{ng} / \mathrm{kg}$ d.w. & 42 \\
\hline WHO-TEQ & 0.80-4.94 ng TEQ/kg d.w. & \\
\hline \multicolumn{3}{|l|}{ Odra River } \\
\hline the sum of PCBs & $3.70-10.80 \mathrm{ng} / \mathrm{kg}$ d.w. & 58 \\
\hline
\end{tabular}

WHO-TEQ - World Health Organization Total Toxic Equivalency; d.w. - dry weight.

Other abbreviations as in Figure 1.

concentration in urban reservoirs $(694.31 \mathrm{pg} / \mathrm{g})$ comparing to those in rural areas $(350.1 \mathrm{pg} / \mathrm{g})$ [24]. In both cases the most abundant congeners were the monoortho PCBs constituting up to $95 \%$ in urban, and up to
$80 \%$ in rural reservoir sediments. Within the mono-ortho PCBs, as well as within the whole dl-PCBs congeners, the highest concentration had the 2,3',4,4',5-pentachlorobiphenyl (PCB-118) (327.3 pg/g and $119.2 \mathrm{pg} / \mathrm{g}$ which 
Table 2. Levels of PCDDs, PCDFs and dl-PCBs and WHO-TEQ concentrations determined in reservoir and river sediments in different locations of the world

\begin{tabular}{|c|c|c|c|}
\hline Country & Measured compounds & Concentration & Reference \\
\hline \multicolumn{4}{|l|}{ Ethiopia } \\
\hline \multirow{2}{*}{$\begin{array}{l}\text { large reservoir (Lake Avassa and Koka } \\
\text { Reservoir) }\end{array}$} & the sum of PCDDs/PCDFs & 63.17-270.39 ng/kg d.w. & 59 \\
\hline & PCDDs/PCDFs WHO-TEQ & 4.04-23.78 ng TEQ/kg d.w. & \\
\hline \multirow[t]{2}{*}{ small reservoir (textile factory pond) } & $\begin{array}{l}\text { the sum of PCDDs/PCDFs } \\
\text { and dl-PCBs }\end{array}$ & $4752.00 \mathrm{ng} / \mathrm{kg}$ d.w. & 57 \\
\hline & WHO-TEQ & 211.95 ng TEQ/kg d.w. & \\
\hline \multicolumn{4}{|l|}{ South Africa } \\
\hline \multirow[t]{2}{*}{ Vaal River - industrialized area } & $\begin{array}{l}\text { the sum of PCDDs/PCDFs } \\
\text { and dl-PCBs }\end{array}$ & $120.00-4900.00$ ng/kg d.w. & 60 \\
\hline & WHO-TEQ & 0.12-16.00 ng TEQ/kg d.w. & \\
\hline \multicolumn{4}{|l|}{ South Korea } \\
\hline \multirow[t]{2}{*}{ Lake Shihwa - in industrialized region } & $\begin{array}{l}\text { the sum of PCDDs/PCDFs } \\
\text { and dl-PCBs }\end{array}$ & $0.04-100.00$ ng/g d.w. & 61 \\
\hline & WHO-TEQ & 0.10-1 600.00 ng TEQ/kg d.w. & \\
\hline \multicolumn{4}{|l|}{ China } \\
\hline $\begin{array}{l}\text { Liaohe River - one of the most polluted } \\
\text { river in China }\end{array}$ & $\begin{array}{l}\text { the sum of PCDDs/PCDFs } \\
\text { WHO-TEQ }\end{array}$ & $\begin{array}{l}\text { 13.74-453.62 ng/kg d.w. } \\
0.24-27.49 \text { ng TEQ/kg d.w. }\end{array}$ & 62 \\
\hline \multicolumn{4}{|l|}{ United Kingdom } \\
\hline $\begin{array}{l}\text { Marsworth Reservoir - small reservoir, } \\
\text { in rural area }\end{array}$ & $\begin{array}{l}\text { the sum of PCDDs/PCDFs } \\
\text { I-TEQ }\end{array}$ & $\begin{array}{l}2000.00 \text { ng/kg d.w. } \\
92.00 \text { ng TEQ/kg d.w. }\end{array}$ & 63 \\
\hline \multicolumn{4}{|l|}{ Switzerland } \\
\hline small and shallow lake east from Zurich & $\begin{array}{l}\text { the sum of PCDDs/PCDFs } \\
\text { WHO-TEQ }\end{array}$ & $\begin{array}{l}300.00 \mathrm{ng} / \mathrm{kg} \text { d.w. } \\
5.00 \mathrm{ng} \mathrm{TEQ} / \mathrm{kg} \text { d.w. }\end{array}$ & 5 \\
\hline \multicolumn{4}{|l|}{ Italy } \\
\hline $\begin{array}{l}\text { Lake Maggiore - the 2nd largest Italian } \\
\text { lake }\end{array}$ & $\begin{array}{l}\text { the sum of WHO-TEQ } \\
\text { PCDDs/PCDFs }\end{array}$ & 0.13-32.00 ng TEQ/kg d.w. & 64 \\
\hline \multicolumn{4}{|l|}{ Japan } \\
\hline Matsuyama River & the sum of PCDDs/PCDFs & $0.95-4.30 \mathrm{ng} / \mathrm{kg}$ d.w. & 30 \\
\hline \multicolumn{4}{|l|}{ Taiwan } \\
\hline $\begin{array}{l}\text { Er-Jen rver - one of the most polluted } \\
\text { rivers in Taiwan }\end{array}$ & $\begin{array}{l}\text { the sum of WHO-TEQ } \\
\text { PCDDs/PCDFs }\end{array}$ & 14.00-14 200.00 ng TEQ/kg d.w. & 31 \\
\hline \multicolumn{4}{|l|}{ USA } \\
\hline $\begin{array}{l}\text { water from the Houston Ship Channel - } \\
\text { industrialized region }\end{array}$ & the sum of PCBs & 4.18-4 601.00 ng/g d.w. & 65 \\
\hline sediments from Kentucky Lake & the sum of PCBs & $580.00-1300.00 \mathrm{ng} / \mathrm{kg}$ d.w. & 66 \\
\hline
\end{tabular}

Abbreviations as in Figure 1 and Table 1. 
constituted $47.14 \%$ and $34.05 \%$ of the dl-PCBs in urban and rural reservoir sediments, respectively). In the case of WHO-TEQ concentration, the higher values were also noted in urban $(1.42 \mathrm{pg} \mathrm{TEQ} / \mathrm{g})$ than in the rural reservoir sediments $(0.40 \mathrm{pg}$ TEQ/g) [24].

The further study of Urbaniak et al. [26], performed in the 5 urban cascade reservoirs located along the Sokołówka River continuum, showed diversified dl-PCBs concentrations ranging from $40.9 \mathrm{pg} / \mathrm{g}$ up to $1000 \mathrm{pg} / \mathrm{g}$ with high contribution of PCB-118 (up to 74\% of the total dl-PCBs). Moreover, the obtained results demonstrated a spatial distribution of dl-PCB along the cascade of urban reservoirs with a decreasing concentration in the 1 st 3 reservoirs (from $243 \mathrm{pg} / \mathrm{g}$ in the 1st reservoir to $40.9 \mathrm{pg} / \mathrm{g}$ in the $3 \mathrm{rd}$ reservoir) and a large increase in the 4th reservoir $(1000 \mathrm{pg} / \mathrm{g})$. The last reservoir also showed an elevated concentration of dl-PCBs - $758 \mathrm{pg} / \mathrm{g}$. In addition, the study of Urbaniak et al. [26] confirmed the high contribution of mono-ortho PCBs (generated mainly by elevated concentration of PCB-118), in the urban reservoirs [24], which contributed up to $95 \%$ of the total dl-PCBs [26].

In the case of rural Sulejowski Reservoir, the average dl-PCBs values were much lower with a significant variation between different sampling points located along the reservoir [29]. Similarly to the results described above from the urban reservoirs, the highest concentrations and thus, percentage content was noticed for PCB-118 congener [42]. The further study of Urbaniak et al. [43] performed in order to assess the role of Sulejowski Reservoir in the transport of micropllutants along the river continuum, showed several times lower dl-PCBs concentrations, ranging from $6.54 \mathrm{pg} / \mathrm{g}$ up to $9.21 \mathrm{pg} / \mathrm{g}$ with higher proportion of mono-ortho PCBs and the WHO-TEQ concentration between $0.25-0.42 \mathrm{pg}$ TEQ/g. Here, it should be underlined, that Sulejowski Reservoir is an eutrophic reservoir constructed in the middle reach of Pilica River and these results, despite the fact that they are still among the lowest reported in literature [29], are of high importance due to the river's recreational function as well as its role as an emergency source of drinking water for the city of Łódź.

To summarize, concentrations of PCDDs/PCDFs and dl-PCBs were higher in the case of sediments collected from the urban catchments; thus, it seems reasonable to suppose that there is a significant contribution of the sources connected with urban areas such as industry, road transport, parking, etc. (Figure 2). The study of Urbaniak et al. [26] focused on the spatial distribution of PCDDs/PCDFs and dl-PCBs along the cascade of urban reservoirs, as the main sources of PCDDs/PCDFs and dl-PCBs in the studied reservoirs depicting atmospheric deposition and further scouring of deposited PCDDs/PCDFs during rains (storm water), industrial and domestic effluents, spills and others. Concentration of PCDDs/PCDFs and dl-PCBs in rural areas in turn, were mainly determined by the diffuse sources of pollution related mostly to agricultural and urban runoff [44]. A similar situation was observed by Liu et al. (2008) in the Xijiang River [45]. The results of the sediment samples from central Poland indicate necessity to continue monitoring of the PCDDs/PCDFs and dl-PCBs concentrations in that area, and particularly in Łódź. At the same time, it is essential to note that contamination of sediments may lead to pollution of other compartments of aquatic ecosystem such as benthic organisms and fish [26].

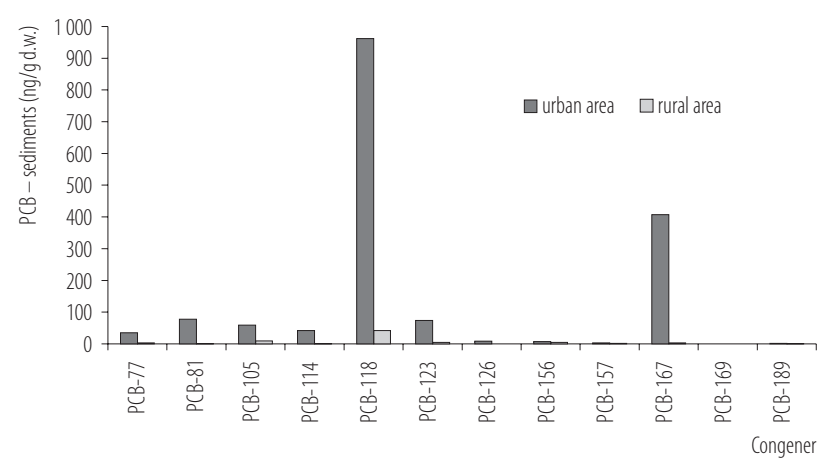

Fig. 2. Concentration of polychlorinated biphenyls (PCB) congeners in rural and urban areas [24] 
As consuming fish offers a significant advantage to human health, it is essential to ensure that water ecosystems including sediments do not threaten the organisms living there. Ling et al. [31] have reported that concentration of PCDDs/ PCDFs in fish from Er-Jen River was very high due to contamination of sediment collected from that river. There seems to be a noticeable connection between sediment pollution and concentration of PCCDs/PCDFs in fish and, consequently, between human intake of PCDDs/PCDFs.

\section{Levels of PCDDs, PCDFs and dl-PCBs}

\section{in the river and reservoirs and storm water}

There are no criteria for the maximum allowable concentration of PCDDs/PCDFs in water in Poland, but the US EPA set this value for 2,3,7,8-tetraCDD in drinking water to be $0.0013 \mathrm{pg} / \mathrm{l}$ [46]. The environmental quality standard in Japan equals $1.0 \mathrm{pg}$ TEQ/1 [47], and $30 \mathrm{pg} / \mathrm{l}$ is the US EPA Maximum Contaminant Level for 2,3,7,8-TCDD [48].

According to Urbaniak et al. [23], rapid development of urban areas leads to changes in stream hydrology and geomorphology, which leads to accelerated fluxes of matter, nutrients and organic pollutants from atmospheric deposition, urban runoff, industry, sewage treatment plants and combined sanitary overflows. In such a situation, urban rivers are frequently used as receivers of a variety of substances. Therefore, the analysis of PCDDs/ PCDFs and dl-PCBs in the urban river, urban reservoirs and storm water collected in the river catchment is of high importance in monitoring of PCDDs/PCDFs and dl-PCBs dynamics and their sources in the urban areas.

The available literature data concerning pollution of urban rivers, confirmed the presence of PCDDs/PCDFs in the water of Sokołówka River and its reservoirs. In the case of the riverine water, the obtained data demonstrated a very low concentration of PCDDs/PCDFs with the highest concentration of $12.53 \mathrm{pg} / \mathrm{l}$ [23] and WHO-TEQ of $0.88 \mathrm{pg} \mathrm{TEQ} / \mathrm{l}$ at maximum.
The results of reservoir water analysis, despite its much higher PCDDs/PCDFs concentration in relation to the river water, also showed seasonal changes with slightly lower values noted in winter (12.04-1327 pg/l) than in the summer time $(26.75-1352 \mathrm{pg} / \mathrm{l})$. The results were obtained in the case of WHO-TEQ level, with concentration of $60.37 \mathrm{pg} T E Q / 1$ and $73.46 \mathrm{pg} T E Q / 1$ observed in the winter and summer samples, respectively [23]. The higher total and WHO-TEQ PCDDs/PCDFs in urban reservoir water samples than those taken from the urban river [23] may be connected with specific character of urban reservoirs as their water quality is determined not only by a range of processes occurring in the relatively large catchment area but also to the considerable buildup of pollutants due to their high water retention and accumulation rates [49].

Seasonal changes, in turn, are mostly related to changes in the water flow occurring due to melting snow or intensive rains, e.g., Cailleaud et al. [50] reported that a higher PCBs concentration was observed during winter high flow season as well as during summer storm events, whereas the lowest concentration was observed in low flow periods. The results obtained in the case of Sokołówka River and its reservoirs, with a lower sum of PCDDs/PCDFs and TEQ in winter low flow, are consistent with the findings presented above and with the results of other researchers [51,52]. Similar results were obtained in the case of rural reservoir. The results of the inflow and outflow water from Sulejowski Reservoir collected during high and low water flows, demonstrated a relatively high pollution level ranging from $87.5 \mathrm{pg} / \mathrm{l}$ to $111 \mathrm{pg} / \mathrm{l}$ during the high water level, and from $38.7 \mathrm{pg} / \mathrm{l}$ to $51.1 \mathrm{pg} / \mathrm{l}$ during the serene water level. At the same time, the WHO-TEQ concentrations ranged from $1.80 \mathrm{pg}$ TEQ/1 to $5.90 \mathrm{pg}$ TEQ/1 during high flows and from $2.10 \mathrm{pg}$ TEQ/1 to $3.40 \mathrm{pg}$ TEQ/l during the serene flow period [44]. This finding confirmed the role of hydrological and 
meteorological conditions in the creation of the final PCDDs/PCDFs concentration.

Considering the pollution of reservoir water, the results obtained by Chen et al. [53] on the basis of water samples from the Three Gorge Dam demonstrated a significantly lower WHO-TEQ concentration (range: 0.0008$0.32439 \mathrm{pg} / \mathrm{l}$ ) than the values noted in the case of the urban (Sokołówka) and rural (Sulejowski) reservoirs [23] described above, as well as other literature data [30]. Nevertheless, it should be emphasized that in contrast to the small, urban Sokołówka reservoirs, the Three Gorge Dam is one of the biggest dam reservoir in the world and plays an important role as a water supply for the Chinese. Thus, maintaining a low level of water contamination is an extremely important issue for public health.

In the case of storm water, the obtained data showed the land-use induced variability in the concentration of PCDDs/PCDFs. The storm water samples taken from the area of the Sokołówka River catchments, demonstrated that the highest contamination level was noted in the samples collected from residential catchment (222.33 pg/l), whereas in residential/industrial and apartmental catchments it amounted to 211.53 and $170.78 \mathrm{pg} / \mathrm{l}$, respectively. However, the WHO-TEQ concentration was the highest in the samples from catchment of mixed residential/industrial impact - $27.52 \mathrm{pg}$ TEQ/1 [54]. The authors depicted that the land use character, types of buildings as well as the presence of industrial plants are very important factors responsible for composition of storm water including Persistent Organic Pollutants like PCDDs/PCDFs and dl-PCBs.

Despite diversified concentrations of $\mathrm{PCDDs} / \mathrm{PCDF}$ and dl-PCBs in Sokołówka River, its reservoirs and storm water collected from its catchment, the congeners pattern were similar [23,54] (Figure 3 and 4). OCDD was the dominant congener in the water from the urban Sokołówka River as well as in urban storm water $[23,54]$. Also, in the case of urban small reservoirs, the OCDD was the one and only congener detected in water samples and thus, the sum of PCDDs/PCDFs was equal to the OCDD concentration $[23,54]$. These results are in agreement with the previously described results of sediments pollution with PCDDs/PCDFs [24,26,28]. A correlation between storm water and sediments was also found as the predominance of OCDD and 2,3,4,6,7,8-hexachlorodibenzofuran (HxCDF) and PCB-118 was observed in both matrices [54]. The similar pattern of PCDDs/PCDFs in the water from Sokołówka River, reservoirs and storm water may be related to the fact that the river is known to be a storm water receiver, as about 50 storm water outlets are located along its length [23,54].

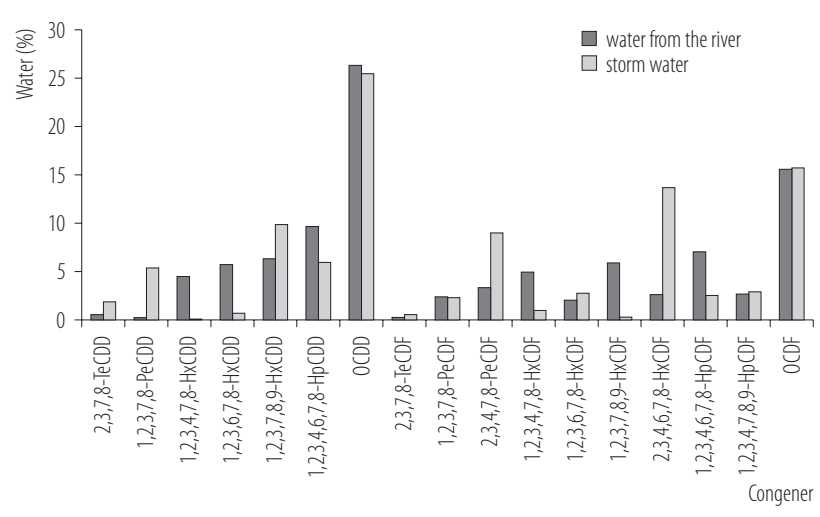

Abbreviations as in Figure 1.

Fig. 3. Polychlorinated dibenzo-p-dioxins/furans (PCDDs/PCDFs) congener profile in the samples of river and storm water

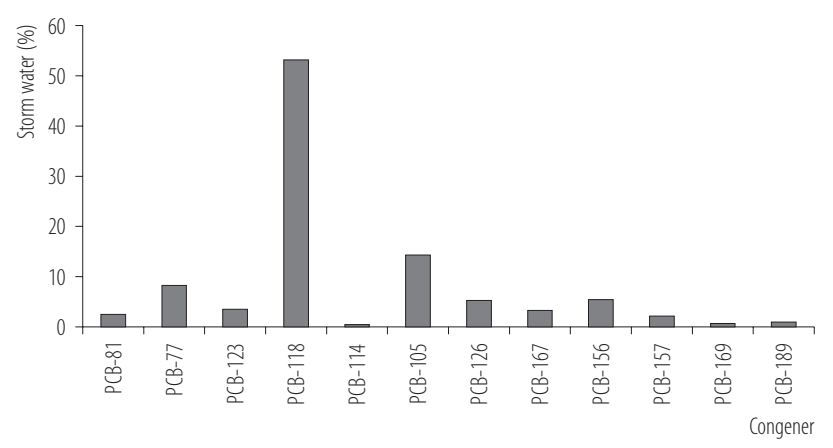

Fig. 4. Dioxin-like polichlorinated biphenyls (dl-PCBs) congener profile in the samples of storm water 
These storm water outlets collect organic and mineral particulate matter as well as associated compounds from a relatively large drainage area, including: roofs, streets, communication nodes, car parks, etc. Moreover, as it has been demonstrated in the study of Urbaniak et al. [23], the predominance of OCDD congener may be related to the illegal discharges of the untreated sewage to Sokołówka River through the storm water outlets located along it [23]. The results from the presented studies focusing on the urban and rural areas in central Poland showed that concentrations of PCDDs/PCDFs and dl-PCBs exhibit considerable variation in the noted values. There is a very alarming tendency of river and reservoir sediments to cumulate PCDDs/PCDFs and dl-PCBs coming from different sources and storm water being one of the major sources, especially in urban setting, in rivers situated in high-urbanized cities [23].

Levels of PCDDs, PCDFs and dl-PCBs and WHO-TEQ concentrations determined in reservoir, river, and storm water in Poland and worldwide are shown in Table 3.

\section{The sum of PCDDs/PCDFs and WHO-TEQ factor}

It is very important to keep in mind that the content of individual congeners in environmental materials can be confusing when we consider only the weight of congeners. The content of OCDD and PCB-118 is usually predominant for most of the environmental samples, nevertheless those 2 congeners are not significant in terms of the risk they pose to human health. Therefore, based on the allowable literature data presenting the congeners profiles in different environmental matrices, the real risk posed by PCDDs/PCDFs and dl-PCBs is expressed as WHO-TEQ coefficient.

Figure 5 shows that OCDD is the predominant congener in sediment as well as water samples. The content of this congener in the samples is over $71 \%$ of all congeners, while the content of 1,2,3,7,8-pentachlorodibenzo-p-dioxin (PeCDD) and 2,3,4,7,8-pentachlorodibenzofuran (PeCDF) is $0.6 \%$ and $2 \%$, respectively. However, those 2 congeners are most significant in TEQ value because of their high toxicity and high toxic

Table 3. Levels of PCDDs, PCDFs and dl-PCBs and WHO-TEQ concentrations determined in reservoir, river, and storm water in Poland and worldwide

\begin{tabular}{|c|c|c|c|}
\hline Country & Measured compounds & Concentration & Reference \\
\hline \multicolumn{4}{|l|}{ Poland } \\
\hline $\begin{array}{l}\text { reservoirs on Sokołówka river } \\
\text { (Łódz) - urbanized area }\end{array}$ & $\begin{array}{l}\text { the sum of PCDDs/PCDFs } \\
\text { WHO-TEQ }\end{array}$ & $\begin{array}{l}12.04-1327.90 \mathrm{pg} / 1 \\
0.004-60.37 \mathrm{pg} \text { WHO-TEQ/1 }\end{array}$ & 23 \\
\hline $\begin{array}{l}\text { storm water in Łódź, in central } \\
\text { Poland - urbanized area }\end{array}$ & $\begin{array}{l}\text { the sum of PCDDs/PCDFs } \\
\text { and PCBs WHO-TEQ }\end{array}$ & $\begin{array}{l}170.78-222.33 \mathrm{pg} / \mathrm{l} \\
27.52 \mathrm{pg} \text { WHO-TEQ/1 }\end{array}$ & 54 \\
\hline \multicolumn{4}{|l|}{ USA } \\
\hline $\begin{array}{l}\text { water from the Houston Ship } \\
\text { Channel - industrialized region }\end{array}$ & the sum of PCBs & $0.49-12.49 \mathrm{ng} / \mathrm{l}$ & 65 \\
\hline \multicolumn{4}{|l|}{ Japan } \\
\hline river water from Matsuyama & the sum of PCDDs/PCDFs & n.d. $-1500.00 \mathrm{pg} / \mathrm{l}$ & 30 \\
\hline \multicolumn{4}{|l|}{ China } \\
\hline $\begin{array}{l}\text { the largest reservoir in China - } \\
\text { plays a significant role in water } \\
\text { supply }\end{array}$ & $\begin{array}{l}\text { the sum of PCDDs/PCDFs } \\
\text { WHO-TEQ }\end{array}$ & $\begin{array}{l}2.10-101.90 \mathrm{pg} / \mathrm{l} \\
0.0008-0.3240 \mathrm{pg} \text { WHO-TEQ/1 }\end{array}$ & 53 \\
\hline
\end{tabular}

n.d. - not detected. Other abbreviations as in Figure 1 and Table 1. 
Table 4. WHO 2005 toxic equivalency factors (TEF) values

\begin{tabular}{|c|c|}
\hline Congener & WHO-TEF \\
\hline \multicolumn{2}{|l|}{ PCDDs } \\
\hline 2,3,7,8-TeCDD & 1.0000 \\
\hline 1,2,3,7,8-PeCDD & 1.0000 \\
\hline 1,2,3,4,7,8-HxCDD & 0.1000 \\
\hline 1,2,3,6,7,8-HxCDD & 0.1000 \\
\hline 1,2,3,7,8,9-HxCDD & 0.1000 \\
\hline 1,2,3,4,6,7,8-HpCDD & 0.0100 \\
\hline OCDD & 0.0003 \\
\hline \multicolumn{2}{|l|}{ PCDFs } \\
\hline 2,3,7,8-TeCDF & 0.1000 \\
\hline $1,2,3,7,8-\mathrm{PeCDF}$ & 0.0300 \\
\hline 2,3,4,7,8-PeCDF & 0.3000 \\
\hline 1,2,3,4,7,8-HxCDF & 0.1000 \\
\hline 1,2,3,6,7,8-HxCDF & 0.1000 \\
\hline 1,2,3,7,8,9-HxCDF & 0.1000 \\
\hline 2,3,4,6,7,8-HxCDF & 0.1000 \\
\hline $1,2,3,4,6,7,8-\mathrm{HpCDF}$ & 0.0100 \\
\hline 1,2,3,4,7,8,9-HpCDF & 0.0100 \\
\hline $\mathrm{OCDF}$ & 0.0003 \\
\hline \multicolumn{2}{|l|}{ Non-ortho-PCBs } \\
\hline 3,3',4,4'-TCB (PCB-77) & 0.0001 \\
\hline 3,4,4',5-ТCB (РCB-81) & 0.0003 \\
\hline 3,3',4,4',5-PeCB (PCB-126) & 0.1000 \\
\hline 3,3',4,4',5,5'-HxCB (РCB-169) & 0.0300 \\
\hline \multicolumn{2}{|l|}{ Mono-ortho-PCBs } \\
\hline 2,3,3',4,4'-PeCB (105) & 0.00003 \\
\hline 2,3,4,4',5-PeCB (114) & 0.00003 \\
\hline 2,3',4,4',5-PeCB (118) & 0.00003 \\
\hline 2',3,4,4',5-РeCB (123) & 0.00003 \\
\hline 2,3,3',4,4',5-НxCB (156) & 0.00003 \\
\hline 2,3,3',4,4',5'-HxCB (157) & 0.00003 \\
\hline 2,3',4,4',5,5'-HxCB (167) & 0.00003 \\
\hline 2,3,3',4,4',5,5'-НpCВ (189) & 0.00003 \\
\hline
\end{tabular}

TCB - tetrachlorobiphenyl; PeCB - pentachlorobiphenyl; HxCB - heksachlorobiphenyl; HpCB - heptachlorobiphenyl. Other abbreviations as in Figure 1 and Table 1.

equivalency factors (TEF) (1 and 0.5, respectively) [55]. Table 4 shows WHO TEF values. A similar situation was demonstrated in the case of dl-PCBs congeners.
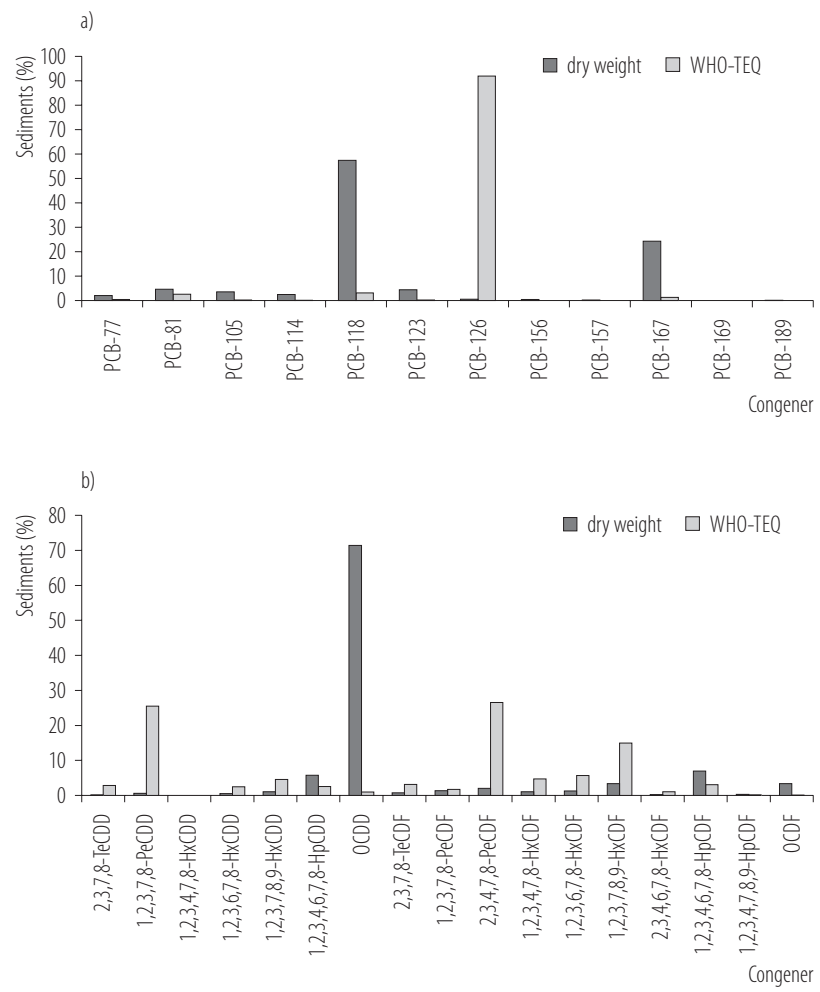

Abbreviations as in Figure 1.

Fig. 5. Profile of a) dioxin-like polichlorinated biphenyls (dl-PCBs) and b) polychlorinated dibenzo-p-dioxins/furans (PCDDs/PCDFs) congeners in terms of $\%$ of dry weight and $\%$ of World Health Organization Total Toxic Equivalency (WHO-TEQ)

The literature data showed predominance of PCB-118 (57\% of all congeners, TEF $=0.00003$ ), while the most essential for the health risk assessment is 3,3',4,4',5-pentachlorobiphenyl (PCB-126) (TEF of 0.5). The conclusion is that WHO-TEQ value is more important than the content of individual or total PCDDs/PCDFs and dl-PCBs congeners, as it is a reliable measure of health hazard.

\section{CONCLUSIONS}

Data on the low pollution with PCDDs/PCDFs and dl-PCBs of pine needles and agricultural soil $[20,21]$ in Poland are in accordance with the results of mothers' milk 
study [16] and with our own data on their diffusion in sediments and surface water in the central region of the country, which were discussed in this article. These results do not support at all the impression of Poland as a significant source of PCDDs/PCDFs and dl-PCBs emissions to the atmosphere as found in a recent model by Shatalov et al. [56]. Monitoring of the PCDDs/PCDFs and dl-PCBs concentrations and patterns in a wide range of river ecosystem matrices including floodplain soil, water, suspended matter, sediments and biota, as well as recognition of the fate of PCDDs/PCDFs and dl-PCBs (transformation/degradation/sedimentation, etc.) allows for:

1. Assessment of their transport along the river continuum and in consequence, quantification of their loadings in individual rivers in order to assess the impact of the tributaries on the quality of main rivers and coastal zones.

2. Identification of the impact of point and diffuse sources of pollution on the river quality. This in turn, will enable to undertake clean-up operations in the river catchments to diminish negative influence of the given pollution source on the river ecosystem and achieve good quality status of water as it is recommend by the Water Framework Directive (2000/60/EU).

\section{REFERENCES}

1. Brink P, Monkhouse C, Füll C, Ladefoged A. Comparative analysis of REACH and other international approaches. Institute for European Environmental Policy; 2003. EP/IVA/2003/09/01.

2. Fiedler H. Sources of PCDD/PCDF and impact on the environment. Chemosphere. 1996;32(1):55-64, http://dx.doi. org/10.1016/0045-6535(95)00228-6.

3. Hartmann P, Grupe A, Neupert M. [PCDDs and PCDFs determination in soil samples from the historic Romer brickyard]. UWSF - Z Umweltchem Ökotox. 1992;4:197201. German.
4. Dyke PH, Foan C, Wenborn M, Coleman PJ. A review of dioxin releases to land and water in the UK. Sci Total Environ. 1997;207(2-3):119-31, http://dx.doi.org/10.1016/ S0048-9697(97)00254-4.

5. Zennegg M, Kohler M, Hartmann PC, Sturm M, Gujer E, Schmid P, et. al. The historical record of PCB and PCDD/F deposition at Greifensee, a lake of the Swiss plateau, between 1848 and 1999. Chemosphere. 2007;67(9):1754-61, http://dx.doi.org/10.1016/j.chemosphere.2006.05.115.

6. PN-EN 1948-3:2006. [Stationary sources emissions - Determination of the mass concentration of PCDDs/PCDFs and dioxin-like PCBs - PART 3: Identification and quantification of PCDDs/PCDFs]. Warszawa: Polski Komitet Normalizacyjny; 2006. Polish.

7. Falandysz J, Szymczyk K. Data on the manufacture, use, inventory and disposal of polychlorinated biphenyls (PCBs) in Poland. Pol J Environ Stud. 2001;10(3):189-93.

8. Falandysz J, Yamashita N, Tanabe S, Tatsukawa R. Composition of PCB isomers and congeners in technical Chlorofen formulation produced in Poland. Int J Environ Anal Chem. 1992;47(2):129-36, http://dx.doi. org/10.1080/03067319208027023.

9. Falandysz J, Nose K, Mostrag A, Ishikawa Y, Noma Y, Sakai S. By-side chlorodibenzo-p-dioxins and chlorodibenzofurans in technical chlorobiphenyl formulations of Aroclor 1268, Chlorofen, and Clophen T 64. J Environ Sci Health A Tox Hazard Subst Environ Eng. 2005;40(9): 1665-78, http://dx.doi.org/10.1081/ESE-200067981.

10. Olendrzyński K, Kargulewicz I. [National inventory of air emissions of persistent organic pollutants]. In: [Implementation of the Stockholm Convention Symposium (GF/POL/SEM.1/R.2), 2002 March 21-22, Warszawa, Poland] [cited 2014 June 25]. Available from: http://www. ios.info.pl/gef/doc/r-2-ik-ko.doc. Polish.

11. Struciński P, Piskorska-Pliszczyńska J, Maszewski S, Góralczyk K, Warenik-Bany M, Mikołajczyk S, et al. $\mathrm{PCDD} / \mathrm{Fs}$ and DL-PCBs intake from fish caught in 
Polish fishing grounds in the Baltic Sea - Characterizing the risk for consumer. Environ Int. 2013;56:32-41, http:// dx.doi.org/10.1016/j.envint.2013.03.002.

12. Piskorska-Pliszczyńska J, Lizak R, Maszewski S, Małagocki P, Wijaszka T. Survey of persistent organochlorine contaminants (PCDD, PCDF, DL-PCB) in Baltic fish and fish meals. Bull Vet Inst Pulawy. 2009;53:825-31.

13. Piskorska-Pliszczyńska J, Maszewski S, Warenik-Bany M, Mikołajczyk S, Góraj L. Survey of persistent organochlorine contaminants (PCDD, PCDF and PCB) in fish collected from Polish Baltic fishing areas. Sci World J. 2012;973292, http://dx.doi.org/10.1100/2012/973292.

14. Lizak R, Piskorska-Pliszczyńska J, Rachubik J, WarenikBany M, Kowalski B. Levels and patterns of polychlorinated dibenzo-p-dioxins, dibenzofurans and dioxin-like polychlorinated biphenyls in Polish foodstuffs of animal origin. Organohalog Compd. 2008;70:2054-7.

15. [Commission Regulation (EC) No. 1881/2006 of 19 December 2006 of setting maximum levels for certain contaminants in foodstuffs (Text with EEA relevance). 20.12.2006 L 364/5]. Polish.

16. Kamińska J, Ligocka D, Zieliński M, Czerska M, Jakubowski M. The use of PowerPrep and HRGC/HRMS for biological monitoring of exposure to PCDD, PCDF and dl-PCB in Poland. Int J Hyg Environ Health. 2014;217(1):11-6, http:// dx.doi.org/10.1016/j.ijheh.2013.02.009.

17. Szyrwińska K, Lulek J. Exposure to specific polychlorinated biphenyls and some chlorinated pesticides via breast milk in Poland. Chemosphere. 2007;66(10):1895-1903, http:// dx.doi.org/10.1016/j.chemosphere.2006.08.010.

18. Czaja K, Ludwicki JK, Góralczyk K, Struciński P. Relationship between two cosecutive lactations and fat level in persistent organochlorine compound concentrations in human brest milk. Chemosphere. 2001;43(4-7):889-93, http:// dx.doi.org/10.1016/S0045-6535(00)00449-5.

19. Hooper K, Hooper K, Petreas MX, She J, Visita P, Winkler J, et al. Analysis of breast milk to assess exposure to chlorinated contaminats in Kazakstan: PCBs and organochlorine pesticides in Southern Kazakstan. Environ Health Perspect. 1997;105(11):1250-4.

20. Wyrzykowska B, Hanari N, Orlikowska A, Bochentin I, Rostkowski P, Falandysz J. et al. Polychlorinated biphenyls and -naphthalenes in pine needles and soil from Poland Concentrations and patterns in view of long-term environmental monitoring. Chemosphere. 2007;67(9):1877-86, http://dx.doi.org/10.1016/j.chemosphere.2006.05.078.

21. Bochentin I, Hanari N, Orlikowska A, Wyrzykowska B, Horii Y, Yamashita N, et al. Polychlorinated dibenzop-dioxins (PCDDs) and -furans (PCDFs) in pine needles of Poland. J Environ Sci Health A Tox Hazard Subst Environ Eng. 2007;42(13):1969-78, http://dx.doi.org/10.1080/ 10934520701627066.

22. Wagner I, Breil P. The role of ecohydrology in creating more resilient cities. Ecohydrol Hydrobiol. 2013;13(2): 113-34, http://dx.doi.org/10.1016/j.ecohyd.2013.06.002.

23. Urbaniak M, Skowron A, Zieliński M, Zalewski M. Hydrological and environmental conditions as key drivers for spatial and seasonal changes in PCDD/PCDF concentrations, transport and deposition along urban cascade reservoirs. Chemosphere. 2012;88(11):1358-67, http://dx.doi. org/10.1016/j.chemosphere.2012.05.040.

24. Urbaniak M, Zieliński M, Wesołowski W, Zalewski M. PCB and heavy metals contamination in bottom sediments from three reservoirs of different catchment characteristics. Pol J Environ Stud. 2008;17:941-9.

25. Urbaniak M, Zieliński M, Wesołowski W, Zalewski M. Polychlorinated dibenzo-p-PCDDs/PCDFs (PCDDs) and polychlorinated dibenzofurans (PCDFs) compounds in sediments of two shallow reservoirs in central Poland. Arch Environ Prot. 2009;35(2):125-32.

26. Urbaniak M, Zieliński M, Kaczkowski Z, Zalewski M. Spatial distribution of PCDDs, PCDFs and dl-PCBs along the cascade of urban reservoirs. Hydrol Res. 2013;44(4):614-30, http://dx.doi.org/10.2166/nh.2012.236.

27. Urbaniak M, Zieliński M, Ligocka D, Zalewski M. A comparative analysis of selected persistent organic pollutants 
(POPs) in reservoirs of different types of anthropopression - Polish and Ethiopian studies. Fresen Environ Bull. 2010;19:2710-9.

28. Urbaniak M. [Comparative analysis of dioxins and dioxinlike compounds in reservoirs of different types of anthropopression] [Ph.D. thesis]. Łódź: University of Lodz; 2009. Polish.

29. Waszak I, Dąbrowska H. Persistent Organic pollutants in two fish species of Percidae and sediment from the Sulejowski Reservoir in central Poland. Chemosphere. 2009;75(9): 1135-43, http://dx.doi.org/10.1016/j.chemosphere.2009.03.001.

30. Seike N, Matsumoto M, Matsuda M, Kawano M, Wakimoto T. Distribution and residue patterns of polychlorinated dibenzo-p-PCDDs/PCDFs and dibenzofurans in coastal, river and pond water and sediments from Matsuyama, Japan. Organohalog Compd. 1998;39:97-100.

31. Ling YC, Soong DK, Lee MK. PCDD/DFs and coplanar PCBs in sediment and fish samples from the Er-Jen river in Taiwan. Chemosphere. 1995;31(3):2863-72, http://dx.doi. org/10.1016/0045-6535(95)00150-7.

32. Hagenmaier H, Dawidowsky N, Weberrub U, Hutzinger O, Schwind KH, Thoma H, et al. Emissions of polychalogenated dibenzodioxins and dibenzofurans from combustion engines. Organohalog Compd. 1990;2:329-34.

33. Geueke KJ, Gessner A, Quass U, Bröker G, Hiester E. $\mathrm{PCDD} / \mathrm{F}$ emissions from heavy duty vehicle diesel engines. Chemosphere. 1999;38(12):2791-2806, http://dx.doi. org/10.1016/S0045-6535(98)00494-9.

34. Ryan JV, Gullett BK. On-road emission sampling of a heavyduty diesel vehicle for polychlorinated dibenzo-p-dioxins and polychlorinated dibenzofurans. Environ Sci Technol. 2000;34(21):4483-9, http://dx.doi.org/10.1021/es991236+.

35. Rappe C. Dioxin patterns and source identification. Fresenius. J Anal Chem. 1994;348(1-2):63-75, http://dx.doi. org/10.1007/BF00321606.

36. Niemirycz E. Halogenated organic compounds in the environment in relation to climate change. Warszawa: Environmental Monitoring Library; 2008.
37. Alcock R, Jones K. Dioxins in the environment: A review of trend data. Environ Sci Technol. 1996;30(11):3133-43.

38. Kannan K, Kober JL, Khim JS, Szymczyk K, Falandysz J, Giesy JP. Polychlorinated biphenyls, polycyclic aromatic hydrocarbons and alkylphenols in sediments from the Odra River and its tributaries, Poland. Toxicol Environ Chem. 2003; 85(4-6):51-60, http://dx.doi.org/10.1080/0277221042000.

39. Niemirycz E, Jankowska D. Concentrations and profiles of $\mathrm{PCDD} / \mathrm{Fs}$ in sediments of major Polish rivers and the Gdansk Basin - Baltic Sea. Chemosphere. 2011;85 (3):525-32, http://dx.doi.org/10.1016/j.chemosphere.2011. 08.014 .

40. Rappe C. Sources of exposure, environmental concentrations and exposure assessment of PCDDs and PCDFs. Chemosphere. 1993;27(1-3):211-25, http://dx.doi.org/10.1016/ 0045-6535(93)90295-G.

41. Kozak Z, Dudzińska M. [Polychlorinated dibenzo-p-dioxins and dibenzofurans - characteristics and impact on the environment]. Monogr Environ Engineer Committee No 6. Polish Academy of Sciences; 2001 [cited 2013 May 20]. Available from: http:/www.kis.pan.pl/index.php/en/publications/ 196-monografie-komitetu-inynierii-rodowiska-polskiejakademii-nauk-2. Polish

42. Urbaniak M, Zieliński M, Wesołowski W, Zalewski M. Sources and distribution of polychlorinated dibenzo-paraPCDDs/PCDFs and dibenzofurans in sediments from urban Cascade Reservoirs, central Poland. Environ Prot Eng. 2009;35(3):93-103.

43. Urbaniak M, Kiedrzyńska E, Zalewski M. The role of a lowland reservoir in the transport of micropollutants, nutrients and the suspended particulate matter along the river continuum. Hydrol Res. 2012;43(4):400-11, http://dx. doi.org/10.2166/nh.2012.108.

44. Urbaniak M, Kiedrzyńska E, Zieliński M, Tołoczko W, Zalewski M. Spatial distribution and reduction of PCDD/ PCDF Toxic Equivalents along the three shallow lowland reservoirs. Environ Sci Pollut Res. 2014;21(6):4441-52, http://dx.doi.org/10.1007/s11356-013-2401-7. 
45. Liu F, Fennel DE. Dechlorination and detoxification of 1,2,3,4,7,8-hexachlorodibenzofuran by a mixed culture containing Dehalococcoides ethenogenes strain 195. Environ Sci Technol. 2008;42(2):602-7, http://dx.doi.org/10.1021/ es071380s.

46. EPA440/5-84-007:1984. US EPA ambient water quality criteria for 2,3,7,8-TCDD. Washington: Office of Water Regulations and Standards; 1984.

47. Minomo K, Ohtsuka N, Hosono S, Nojiri K, Kawamura K. Seasonal change of PCDDs/PCDFs/DL-PCBs in the water of Ayase River, Japan: Pollution sources and their contributions to TEQ. Chemosphere. 2011;85(2):188-94, http:// dx.doi.org/10.1016/j.chemosphere.2011.06.033.

48. EPA United States Environmental Protection Agency [Internet]. EPA Drinking Water Contaminant [updated 2013 June 3; cited 2013 May 20]. Available from: http://water.epa. gov/drink/contaminants.

49. Tarczyńska M, Romanowska-Duda Z, Jurczak T, Zalewski M. Toxic cyanobacterial blooms in a drinking water reservoir - Causes, consequences and management strategy. Water Sci Technol Water Suppl. 2001;1(2):237-46.

50. Cailleaud K, Forget-Leray J, Hilde D, LeMenach K, Budzinski $\mathrm{H}$. Seasonal variations of hydrophobic organic contaminant concentrations in the water-column of the Seine Estuary and their transfer to the planctonic species Eurytemora affinis (Calanoïda, Cocepoda). Part 1: PCBs and PAHs. Chemosphere. 2007;70(2):270-80, http://dx.doi.org/10.1016/ j.chemosphere.2007.05.095.

51. Kawamura K, Kaplan IR. Compositional change of organic matter in rainwater during precipitation events. Atmos Environ. 1986;20(3):527-35, http://dx.doi.org/10.1016/00046981(86)90093-4.

52. Gregor DJ, Peters AJ, Teixeira C, Jones N, Spencer C. The historical residue trend of PCBs in the Agassiz Ice Cap, Ellesmere Island, Canada. Sci Total Environ. 1995;160-1: 117-26, http://dx.doi.org/10.1016/0048-9697(95)04349-6.

53. Chen JA, Luo J, Qiu Z, Xu C, Huang Y, Jin YH, et al. PCDDs/PCDFs and PCBs in water samples from the Three
Gorge Reservoir. Chemosphere. 2008;70(9):1545-51, http:// dx.doi.org/10.1016/j.chemosphere.2007.08.063.

54. Urbaniak M, Zalewski M. Temporal and land-use induced variability of $\mathrm{PCDDs} / \mathrm{PCDF}$ and dioxin-like compounds in urban run-off. In: 5th Balwois Conference: International Conference on Water, Climate and Environment, 2012 May 28 - June 2; Ohrid 2012, Republic of Macedonia [cited 2013 May 20]. Available from: http://ocs.balwois.com/index.php?c onference $=$ BALWOIS $\&$ schedConf $=$ BW2012 $\&$ page $=$ pape r\&op=view\&path []$=484 \&$ path []$=534$.

55. van den Berg M, Birnbaum L, Denison M, de Vito M, Farland W, Feeley M, et al. The 2005 World Health Organization reevaluation of human and mammalian Toxic Equivalency Factors for PCDDs/PCDFs and dioxin-like compounds. Toxicol Sci. 2006;93(2):223-41, http://dx.doi.org/10.1093/ toxsci/kfl055.

56. Shatalov V, Johansson JH, Wilberg K, Cousins IT. Tracing the origin of dioxins in Baltic air using an atmospheric modeling approach. Atmos Pollut Res. 2012;3:408-16, http:// dx.doi.org/10.5094/APR.2012.047.

57. Urbaniak M, Skowron A, Frątczak W, Zieliński M, Wesołowski W. Transport of polychlorinated biphenyls in urban cascade reservoirs: Levels, sources and correlation to the environmental conditions. Pol J Environ Stud. 2010;19:201-11.

58. Wolska L, Galer K, Namieśnik J. Transport and speciation of PAHs and PCBs in a river ecosystem. Pol J Environ Stud. 2003;12:105-10.

59. Urbaniak M, Zalewski M. Polychlorinated dibenzo-pPCDDs/PCDFs and polychlorinated dibenzofurans in sediments from two Ethiopian Rift Valley lakes. Pol J Environ Stud. 2011;20:1069-74.

60. Nieuwoudt C, Quinn LP, Pieters R, Jordaan I, Visser M, Kylin H, et. al. Dioxin-like chemicals in soil and sediment from residential and industrial areas in central South Africa. Chemosphere. 2009;76(6):774-83, http://dx.doi.org/10.1016/ j.chemosphere.2009.04.064.

61. Moon HB, Choi M, Choi HG, Kannan K. Severe pollution of PCDD/Fs and dioxin-like PCBs in sediments from 
Lake Shihwa, Korea: Tracking the source. Mar Pollut Bull. 2012;64(11):2357-63, http://dx.doi.org/10.1016/j.marpolbul. 2012.08.018.

62. Zhang H, Zhao X, Ni Y, Lu X, Chen J, Su F, et al. PCDD/Fs and PCBs in sediments of the Liaohe River, China: Levels, distribution, and possible sources. Chemosphere. 2010;79(7): 754-62, http://dx.doi.org/10.1016/j.chemosphere.2010.02.039.

63. Rose Cl, McKay WA. PCDDs (dioxins) and PCDFs (furans) in selected UK lake and reservoir sites - Concentrations and TEQs in sediment and fish samples. Sci Total Environ. 1996;177 (1-3):43-56, http://dx.doi.org/10.1016/0048-9697(95)04858-8.

64. Umlauf G, Canuti E, Castro-Jimenez J, Christoph EH, Eisenreich SJ, Ghiani M, et al. Spatial distribution of
$\mathrm{PCDD} / \mathrm{F}$ in surface sediments of lake Maggiore (Italy). Organohalog Compd. 2006;68:1141-5.

65. Howell NL, Suarez MP, Rifai HS, Koenig L. Concentrations of polychlorinated biphenyls (PCBs) in water, sediment, and aquatic biota in the Houston Ship Channel, Texas. Chemosphere. 2008;70(4):593-606, http://dx.doi.org/10.1016/j.chemosphere.2007.07.031.

66. Loganathan BG, Kumar KS, Masunaga S, Sajwan KS. Polychlorinated dibenzo-p-PCDDs/PCDFs, dibenzofurans, and dioxin-like polychlorinated biphenyls in sediment and mussel samples from Kentucky Lake, USA. Arch Environ Contam Toxicol. 2008;54(1):20-30, http://dx.doi.org/10.1007/ s00244-007-9006-4.

This work is available in Open Access model and licensed under a Creative Commons Attribution-NonCommercial 3.0 Poland License - http://creativecommons.org/ licenses/by-nc/3.0/pl/deed.en. 